\title{
RIGHT TO COUNSEL IN FEDERAL COLLATERAL ATTACK PROCEEDINGS: SECTION 2255
}

Twenty-four years ago the Supreme Court handed down the now famous decision of Johnson v. Zerbst. ${ }^{1}$ Noting that the accused "requires the guiding hand of counsel at every step in the proceedings against him," the Court concluded that: "The Sixth Amendment withholds from federal courts, in all criminal proceedings, the power and authority to deprive an accused of his life or liberty unless he has or waives the assistance of counsel."2 In Johnson v. United States ${ }^{3}$ and Ellis v. United States, ${ }^{4}$ per curiam opinions written in 1957 and 1958, the right to counsel was extended to federal criminal appeals. The recent decision in Coppedge $v$. United States 5 indirectly reaffirmed that extension.

Although the Supreme Court has upheld the right to counsel for criminal trials and appeals in the federal courts, it has not yet decided whether the right exists in a third substantial area of federal criminal litigation: the collateral attack proceedings under section 2255 of the Judicial Code 6 and the habeas corpus statutes.7

1304 U.S. 458 (1938).

2 Id. at 463 . The Court used the word "proceedings" instead of the amendment term "prosecutions," which indicates that it might have been fixing an interpretation of the amendment that would include proceedings beyond the trial stage.

Four years after Johnson v. Zerbst, in Betts v. Brady, 316 U.S. 455 (1942), a divided Court refused to extend the Johnson v. Zerbst rule to criminal prosecutions in the state courts, adopting instead a "fundamental fairness" test to determine the prisoner's right to counsel when tried under state law. However, the Betts v. Brady fairness test, a source of almost continuous litigation at the Supreme Court level since its inception, was recently overruled in Gideon v. Wainwright, 83 Sup.Ct. 792 (1963), by a unanimous Court. While the Gideon Court agreed with the assumption in Betts v. Brady "that a provision of the Bill of Rights which is 'fundamental and essential to a fair trial' is made obligatory upon the States by the Fourteenth Amendment," it held that the Court in Betts v. Brady was wrong "in concluding that the Sixth Amendment's guarantee of counsel is not one of these fundamental rights." Id. at 795. For a complete discussion of the right to counsel in state criminal proceedings, see Kamisar, The Right to Counsel and the Fourteenth Amendment: A Dialogue on "the Most Pervasive Right" of an Accused, 30 U. Crr. L. Rev. 1 (1962).

3352 U.S. 565 (1957).

4356 U.S. 674 (1958).

5369 U.S. 438 (1962) (5-2 decision). Some gaps still remain in the appellate procedure, such as the interim period between conviction and appointment of appeal counsel, when the indigent prisoner is often left to his own devices to get necessary papers filed in time to maintain appellate privileges. See Boskey, The Right to Counsel in Appellate Proceedings, 45 MINN. L. REV. 783 (1961).

628 U.S.C. $\$ 2255$ (1958):

"A prisoner in custody under sentence of a court established by Act of Congress claiming the right to be released upon the ground that the sentence was imposed in violation of the Constitution or laws of the United States, or that the court was without jurisdiction to

[Footnote 6 continued on p. 584]

728 U.S.C. §§ 2241-52 (1958). 
The circuit courts have frequently considered the question of the right to counsel in section 2255 proceedings since the statute was added to the Judicial Code in 1948. The majority rule appears to be that there is no such right. However, a number of courts follow the view that the right is contingent upon the nature of the issues raised by the motion. Furthermore, one case may suggest that there is an absolute right to counsel in all section 2255 proceedings. 8 The diversity of these rules and their rationales indicates the desirability of a unifying decision on the question.

The object of this comment is to examine the lines of circuit court decisions with a view toward determining: (1) Which rule is more consonant with concepts of fair criminal procedure, and (2) whether the refusal to extend the right to counsel to include section 2255 proceedings can be justified in view of the Supreme Court's application of the right in other federal criminal litigation.

Section 2255 motions to vacate sentence are, by the terms of the statute, either substitutes for, or required preliminary actions to, habeas corpus proceedings. 9 They therefore currently give rise to much of the collateral attack

impose such sentence, or that the sentence was in excess of the maximum authorized by law, or is otherwise subject to collateral attack, may move the court which imposed the sentence to vacate, set aside, or correct the sentence.

"A motion for such relief may be made at any time.

"Unless the motion and the files and records of the case conclusively show that the prisoner is entitled to no relief, the court shall cause notice thereof to be served upon the United States attorney, grant a prompt hearing thereon, determine the issues and make findings of fact and conclusions of law with respect thereto. If the court finds that the judgment was rendered without jurisdiction, or that the sentence imposed was not authorized by law or otherwise open to collateral attack, or that there has been such a denial or infringement of the constitutional rights of the prisoner as to render the judgment vulnerable to collateral attack, the court shall vacate and set the judgment aside and shall discharge the prisoner or resentence him or grant a new trial or correct the sentence as may appear appropriate.

"A court may entertain and determine such motion without requiring the production of the prisoner at the hearing.

"The sentencing court shall not be required to entertain a second or successive motion for similar relief on behalf of the same prisoner.

"An appeal may be taken to the court of appeals from the order entered on the motion as from a final judgment on application for a writ of habeas corpus.

"An application for a writ of habeas corpus in behalf of a prisoner who is authorized to apply for relief by motion pursuant to this section, shall not be entertained if it appears that the applicant has failed to apply for relief, by motion, to the court which sentenced him, or that such court has denied him relief, unless it also appears that the remedy by motion is inadequate or ineffective to test the legality of his detention." infra.

8 United States v. Paglia, 190 F.2d 445 (2d Cir. 1951). See text accompanying notes 72-73

9 See note 6 supra, seventh paragraph, and the discussion of the section in Hayman v. United States, 342 U.S. 205, 210-20 (1952); Parker, Limiting the Abuse of Habeas Corpus, 8 F.R.D. 171 (1949). It is because of $\$ 2255$ 's priority position over habeas corpus in the area of collateral attack that it alone is herein discussed. 
litigation under federal criminal law.10 The problem of right to counsel in this context arises only in the case of the indigent prisoner, as the courts do not limit the solvent prisoner's access to his own counsel in the proceedings. 11

Although section 2255 has no provision concerning the representation of the prisoner by counsel, 12 the indigent applicant may petition the court for appointment of counsel to assist him under the provisions of the federal in forma pauperis statute. ${ }^{13}$ Section 1915 (a) ${ }^{14}$ allows any federal court to authorize the commencement of any action or proceeding or appeal by an indigent in that court without prepayment of court fees or costs. Section 1915(d)15 states merely that the court "may request" counsel to represent the indigent. There is no further statutory guarantee that the indigent movant will have the aid of counsel.16

\section{I}

The circuit courts which have held that the indigent prisoner proceeding under section 2255 has no right to counsel have advanced two basic arguments in support of their position:

10 "The very purpose of $\$ 2255$ is to hold any required hearing in the sentencing court because of the inconvenience of transporting court officials and other necessary witnesses to the district of confinement." Hayman v. United States, 342 U.S. 205, 220-21 (1952). Habeas corpus actions must be brought in the district of confiement. Ahrens v. Clark, 335 U.S. 188 (1948). No figures are available to show how many collateral attack actions have been brought by way of habeas corpus since $\$ 2255$ was enacted. It appears that 538 motions to vacate under $\S 2255$ were commenced in the district courts in the fiscal year 1960 . As of June 30, 1960, 113 motions were pending. 1960 DIRECTOR OF THE AD. OFFICE OF THE U.S. Courts ANN. ReP. 231, 241.

11 This is also the case in criminal appeals and, of course, in criminal trials.

12 The section deals with the representation of the prisoner at the hearing only insofar as it states that the court need not require the production of the prisoner at the hearing. See note 6 supra, fourth paragraph.

1328 U.S.C. $\$ 1915$ (1958), as amended, 28 U.S.C. $\$ 1915$ (Supp. III, 1962).

14 "Any court of the United States may authorize the commencement, prosecution or defense of any suit, action or proceeding, civil or criminal, or appeal therein, without prepayment of fees and costs or security therefor, by a person who makes affidavit that he is unable to pay such costs or give security therefor. Such affidavit shall state the nature of the action, defense or appeal and affiant's belief that he is entitled to redress.

"An appeal may not be taken in forma pauperis if the trial court certifies in writing that it is not taken in good faith." 28 U.S.C. $\$ 1915$ (a) (1958), as amended, 28 U.S.C. § 1915 (Supp. III, 1962).

15 "The court may request an attorney to represent any such person unable to employ counsel and may dismiss the case if the allegation of poverty is untrue, or if satisfied that the action is frivolous or malicious." 28 U.S.C. $\$ 1915$ (d) (1958), as amended, 28 U.S.C. \$1915(d) (Supp. III, 1962).

16 It ought to be noted here that the Supreme Court had the discretionary language of $\$ 1915$ (d), that the court "may request counsel," before it in Johnson $v$. United States and Ellis v. United States, since the petitioners for leave to appeal in both of those cases had invoked the in forma pauperis statute. Although the Court went beyond the terms of $\$ 1915$ (d) to find a right to counsel in both cases, that right applies only to in forma pauperis appellants. 
(a) The constitutional guarantee of assistance of counsel as provided in the sixth amendment does not apply to collateral attack actions. ${ }^{17}$

(b) The collateral attack action is not a criminal proceeding by nature, and has in fact been classified as civil in form; therefore standards of fair criminal procedure do not apply. ${ }^{18}$

(A) The argument that the sixth amendment guarantee of counsel does not apply to section 2255 proceedings. - The Fourth Circuit in Crowe v. United States, 19 the Seventh Circuit in United States v. Caufield 20 and the Tenth Circuit in Tubbs $v$. United States 21 have taken the position that there is no constitutional right to counsel under section 2255 proceedings because the sixth amendment only provides for assistance of counsel in every criminal prosecution. This position can be supported by taking a strict view of the sixth amendment term "prosecution." However, it ignores the possible guarantee of counsel embodied in the due process provision of the fifth amendment. It also ignores the fact that criminal appeals, section 2255 actions and even habeas corpus procedure as now prescribed by sections $2244-53$ of the Judicial Code were not yet a part of federal law when the Constitution was framed. To read the sixth amendment term "prosecution" as a limitation on the right to counsel in the newer federal criminal actions may thus advance an obsolete interpretation and in effect overrule the accomplished extension of the right to counsel to include criminal appeals.

If section 2255 is placed in proper historical perspective, it would seem to be highly inconsistent to extend the right to counsel under the sixth amendment to appeals and withhold it from the section 2255 proceeding because it is not a "prosecution." The Supreme Court has taken note of the fact that section 2255 creates a remedy in the nature of the ancient writ of error coram nobis. 22 Beyond the fact that the statute was enacted to correct specific abuses of habeas

17 Tubbs v. United States, 249 F.2d 37, 38-39 (10th Cir. 1957), cert. denied, 355 U.S. 935 (1958); United States v. Caufield, 207 F.2d 278, 280 (7th Cir. 1953); Crowe v. United States, 175 F.2d 799, 801 (4th Cir. 1949), cert. denied, 338 U.S. 950 (1950); cf. Richardson v. United States, 199 F.2d 333 (10th Cir. 1952); Green v. United States, 158 F. Supp. 804, 807 (D. Mass.), aff'd, 256 F.2d 483 (1st Cir.), cert. denied, 358 U.S. 854 (1958).

18 Richardson v. United States, 199 F.2d 333 (10th Cir. 1952); cf. United States v. Caufield, 207 F.2d 278, 280 (7th Cir. 1953).

19175 F.2d 799, 801 (4th Cir. 1949).

20207 F.2d 278, 280 (7th Cir. 1953).

21249 F.2d 37, 38-39 (10th Cir. 1957).

22 United States v. Hayman, 342 U.S. 205 (1952). "This section . . . creates a statutory remedy consisting of a motion before the court where the movant has been convicted. The remedy is in the nature of, but much broader than coram nobis. The motion remedy basically covers all situations where the sentence is "open to collateral attack." "Id. at 216-17 (quoting from a statement by the Judicial Conference Committee on Habeas Corpus Procedure, which recommended legislation that later became $\$ 2255$ ). "This section restates, clarifies and simplifies the procedure in the nature of the ancient writ of error coram nobis. It provides an expeditious remedy for correcting erroneous sentences without resort to habeas corpus.' " Id. at 218 (quoting from the Reviser's Note to $\$ 2255$ ). 
corpus as a collateral attack action, it seems to have been declaratory of existing coram nobis criminal case law in the federal courts. ${ }^{23}$ As to the history of the coram nobis writ, which was originally employed primarily in civil cases, it has been stated that the function of the writ "has not changed from its earliest use in the sixteenth century until today. ... The efficacy of the writ lies in the fact that it is employed to vacate a judgment of conviction predicated on an error in fact unknown to the court. Moreover, these errors in fact could not have been brought to the attention of the appellate court by appeal since they did not appear in the record."'24 This being a fair summary of the nature of section 2255, it becomes apparent that the action has an even closer relation to a prosecution than the direct appeal. On appeal the validity of the trial court's judgment will be reviewed on the basis of the record. A section 2255 proceeding lies in the trial court, providing opportunity for that tribunal to make appropriate corrections in its judgment in light of considerations not before it at the time of the original action.

Crowe, Caufield and Tubbs were all decided before the Supreme Court handed down its opinions in Johnson v. United States 25 and Ellis v. United States.26 Johnson and Ellis both involved applications for leave to appeal in forma pauperis which had been denied by the circuit court. In both cases, the Supreme Court held that leave to appeal was improperly denied, even though the lower courts had found that the appeals were not taken in good faith because the indigent petitioners were not afforded sufficient assistance, including help of counsel, in presenting their applications.

If the Johnson and Ellis decisions were based solely upon the sixth amendment, Crowe, Caufield and Tubbs might seem consonant. The Johnson opinion stated that the appellant was entitled to counsel "under" Johnson v. Zerbst,27 and in reaffirming the right, Ellis cited only Johnson v. United States. The Johnson v. Zerbst decision was specifically based on the sixth amendment.28 It is thus a fair argument that Johnson $v$. United States, on its face, stands only for the extension of the sixth amendment term "prosecution" to include the statutorily guaranteed direct appeal from trial. Under this contention, Crowe, Caufield and Tubbs demonstrate possible grounds for distinguishing the question of right to counsel under section 2255: Since the collateral attack deals

23 Parker, supra note 9, at 175. Judge Parker, who served as chairman of the Judicial Conference Committee on Habeas Corpus Procedure, cites, among other cases, Roberts v. United States, 158 F.2d 150 (4th Cir. 1946), as support for the proposition.

24 FraNk, CoRAM NoBis 1 (1953). Frank presents a more detailed history of the writ as it developed at common law. Much of his book is devoted to the use of the writ in New York since it was accorded full recognition for criminal cases by the New York courts in the 1940's. It is interesting to note that valid bases for relief under the New York writ parallel those recognized by the federal courts under $\$ 2255$.

25352 U.S. 565 (1957). $\quad 26356$ U.S. 674 (1958). $\quad 27304$ U.S. 458 (1938).

28 See text accompanying note 2 supra. 
not with guilt but rather with a basic impropriety of the trial itself, it is invalid to classify such proceedings as an extension of the trial.

It has already been shown that section $\mathbf{2 2 5 5}$ actions would seem historically to be closely related to the original trial. There is a further argument in answer to the contention that they are not a part of the prosecution. The concept of "prosecution" is functional; the number of separate steps in the guilt-determining and sanction-imposing process which are embraced therein may vary. As the Supreme Court observed in Hamilton v. Alabama, 29 what is a prosecution for one purpose of criminal procedure need not be determinative when the question is the right to counsel. To limit the use of prosecution to include only the process of determining in the first instance whether the accused committed the crime tends to ignore the fact that it is also a function of the trial to determine and impose criminal sanction. In light of this aspect, any action that tests the fairness of the imposition of sentence might be viewed as an extension of the trial. Providing a fair means for reviewing the judgment and sentence apart from the establishment or admission of guilt is especially desirable in view of the high percentage of federal criminal convictions that result from guilty pleas. 30 Just as a conviction based on illegally seized evidence will be set aside, 31 so also is it improper to convict an accused who pleads guilty because he was coerced or tricked. The prisoner's only protection against the latter types of conviction in the federal courts is the collateral attack action.

Both Johnson and Ellis may have been grounded on due process principles as well as the sixth amendment guarantee of assistance of counsel in the criminal prosecution. Unfortunately, however, both opinions omit any detailed discussion or justification of their holdings. The Johnson opinion, after citing Johnson v. Zerbst, 32 went on to state that the case would be remanded to the circuit court because that court "did not assign counsel to assist petitioner," and because petitioner was not assured "adequate means" of presenting his application for leave to appeal. ${ }^{33}$ Since the case involved the right to trial transcript as well as the right to counsel, it is not clear whether "adequate means" referred to the supplying of transcript or to the appointment of

29368 U.S. 52 (1961). The Court quoted from Tomkins v. Missouri, 323 U.S. 485, 489 (1945), a capital case: "The guiding hand of counsel is needed at the trial "lest the unwary concede that which only bewilderment or ignorance could justify or pay a penalty which is greater than the law of the State exacts for the offense which they in fact and in law committed." "Hamilton v. Alabama, supra, at 54-55. It then went on to find a right to counsel at arraignment because Alabama law made that procedure an integral part of the guilt-fixing process.

30 In the fiscal year 1960, of 26,728 criminal convictions in the federal district courts, 24,245 resulted from guilty pleas. 1960 DIRECTOR OF THE AD. OFFICE OF THE U.S. COURTS ANN. REP. 304.

31 Mapp v. Ohio, 367 U.S. 643 (1961).

32304 U.S. 458 (1938).

33 Johnson v. United States, 352 U.S. 565, 566 (1957). 
counsel. In either case, the reference to adequacy in the appeal proceedings would appear to draw due process into the decision.

In Ellis, the circuit court had appointed two attorneys to assist petitioner with his application for leave to appeal, but the Supreme Court found that the attorneys had filled the role of amici curiae and held that the services of an advocate were "required." 34 No indication was given as to just what law required the appointment of an advocate. Johnson said nothing about the kind of legal assistance that must be afforded, and Ellis did not mention the sixth amendment guarantee itself. However, the Court's concern seemed to center around the adequacy of the procedure.

Coppedge v. United States, 35 the most recent and exhaustive Supreme Court opinion dealing with the rights of indigents under federal criminal appeal procedure, indicates that the Court is strongly moved by considerations of due process in this area of the law. The primary question before the Court was the standard to be applied by the lower federal courts in passing upon applications for leave to appeal in forma pauperis. ${ }^{36}$ The Court, however, laid down rules for the lower courts that included directions as to appointment of counsel. The rules are clearly directed at establishing standard fair procedure. A substantial portion of the opinion deals with the vitality of the need for "prompt, eminently fair and sober criminal law procedures." 37

It is not inevitable that the question of right to counsel can be resolved only under the sixth amendment. If guaranteeing counsel under section 2255 would assure a more just criminal procedure system, the concept of due process is broad enough to include such a guarantee. The fact that the proceeding is not technically a "prosecution" thus becomes irrelevant.

(B) The argument that the section 2255 proceeding is not a criminal action.In Exparte Tom Tong, 38 the Supreme Court, in determining its own jurisdiction, held that habeas corpus proceedings are civil actions. ${ }^{39}$ In Green v. United States, 40 the section 2255 proceeding was similarly held to be a civil action "for the purposes of the docket of this Court and of reports to the Administrative Office of the United States Courts."41 In United States v. Hayman, 42 the Supreme Court noted in dictum that "unlike the criminal trial where the guilt of the defendant is in issue ... a proceeding under section 2255 is an independent and collateral inquiry into the validity of the conviction." 43 This latter position has been taken by the Seventh Circuit in Caufield 44 and by the Tenth Circuit

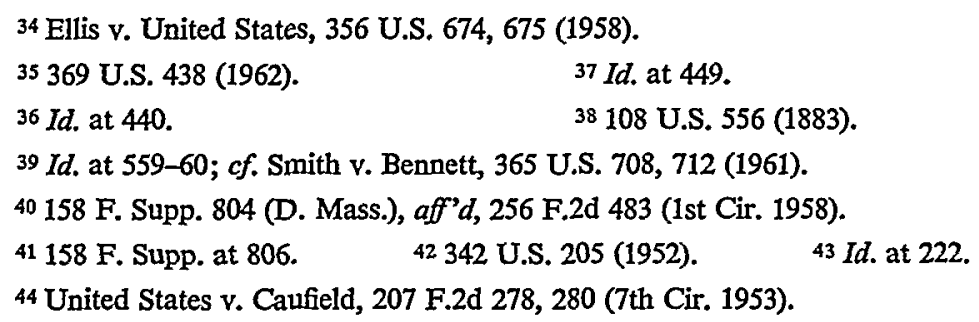


in Richardson $v$. United States, 45 when holding against the right to counsel. In addition, one district court 46 and two commentators 47 have indicated that the Hayman dictum is a proper basis for withholding the right.

The Supreme Court, however, recently rejected the "civil" classification of habeas corpus proceedings as determinative of the prisoner's rights in those proceedings: "The availability of a procedure to retain liberty lost through criminal process cannot be made contingent upon a choice of labels."48 The district court in Green v. United States 49 did not accept the labeling of the section 2255 action as "a special civil rather than a criminal proceeding" for purposes of determining the prisoner's right to counsel. That court chose to view the proceeding as "a sort of hybrid."50 The Ninth Circuit recently conceded that classifying section 2255 actions as "civil" did not provide a proper basis for denial of right to counsel: "Realistically, a proceeding which may result in vacating a criminal judgment is, at least, not purely civil."s1

It would be more reasonable to determine the prisoner's rights under section 2255 in light of the action's implicit criminal nature-its added protection for the prisoner against the loss of life or liberty through a specifically improper trial or sentence. Conceding that the proceedings are basically criminal does not, however, remove the possibility that refusal to extend the right to counsel to those proceedings might be justified because the nature of the action is such that "the same need for counsel is not invariably present" under section 2255 as in the case of trial or appeal.52

In spite of this suggested possibility, it is nowhere demonstrated that aid of counsel is any less necessary in order for the prisoner to employ section 2255 effectively than it is to assure him of an adequate appeal or trial. This is particularly significant if the trial court grants the prisoner a hearing on his motion. Given that the court has determined that the prisoner may have a valid point to raise, 53 he is in just as great need of technical assistance in

45199 F.2d 333 (10th Cir. 1952).

46 Motion of Davis, 92 F. Supp. 524, 526 (D. Mont. 1949).

47 Boskey, supra note 5, at 799; Qua, Griffin v. Illinois, 25 U. CHI. L. REv. 143, 149-50 (1957).

${ }^{48}$ Smith v. Bennett, 365 U.S. 708, 712 (1961).

49158 F. Supp. 804, 807 (D. Mass.), aff'd, 256 F.2d 483 (1st Cir. 1958).

50158 F. Supp. at 807.

51 Dillon v. United States, 307 F.2d 445, 446 n. 3 (9th Cir. 1962).

52 Ibid.

53 Under $\$ 2255$, a hearing must be granted unless the motion, and the files and records of the case, conclusively show that the prisoner is entitled to no relief. See note 6 supra, third paragraph. 
litigating this point as is the defendant or appellant who by hypothesis also has an arguable point to make. It is an untenable proposition that the indigent prisoner will be able to proceed fairly on the strength of his own technical knowledge in the section 2255 proceeding. The section 2255 motion is a procedure by which the prisoner may regain liberty lost through the criminal process. It is just as important that he be guaranteed the effective use of this collateral attack procedure as it is that he be given adequate assurance that he will not in the first instance be unfairly deprived of his freedom.

II

If it is conceded that in the interest of fairness and effectiveness the movant ought to have the assistance of counsel, the question remains as to the possible limitation upon the furnishing of free aid to the indigent prisoner.

In denying the right to counsel under section 2255 , one circuit court has held, without further justification, that the appointment of counsel for the indigent prisoner rests within the sound discretion of the trial court.54 As noted previously, section 1915(d) clears the way for such a holding by providing, without specificity, that the court may appoint counsel in proceedings in forma pauperis. 55

The drawback inherent in leaving appointment of counsel within the discretion of the trial court, without saying more, is that no standards are advanced by which the trial court can employ its discretion. Similarly, the appellate courts are left without criteria for considering the possible abuse of the trial court's discretion. 56

This is not to say, however, that the only conclusion must be that free allowance of counsel to the indigent prisoner is in order. Such unrestricted allowance might well lead to abuse at the hands of the poor prisoner who searches through the prison law books trying to find new ways to regain freedom. A safeguard against such abuse is undoubtedly necessary, especially in view of the facts that section 2255 may be invoked at any time while the prisoner is still in jail 57 and that the same prisoner may file successive motions so long as they do not seek "similar relief." 58

If the trial court is to have discretion as to the appointment of counsel, what should be the scope of that discretion? The Seventh Circuit has recently indicated that the trial court is justified in disallowing counsel if the prisoner's

54 Richardson v. United States, 199 F.2d 333 (10th Cir. 1952); cf. Crowe v. United States, 175 F.2d 799, 801 (4th Cir. 1949).

5s See text accompanying notes 14-15 supra.

56 Under $\$ 2255$, appeals may be taken from a final order on the motion by the trial court. See note 6 supra, sixth paragraph.

57 Id., first paragraph.

58 Id., fifth paragraph. It is also significant that the number of $\$ 2255$ motions filed and rejected is great. 
motion demonstrates no grounds for relief. 59 It is submitted that this standard unduly limits the effectiveness of the indigent prisoner's motion. Without aid of counsel to assist him in preparing the motion, the indigent will be handicapped in attempting to present one that will demonstrate some right to relief. To say that the prisoner must first present a valid motion before he may have assistance tends to say that he must first demonstrate that he does not need aid before he may receive it.

The Supreme Court handed down its rulings on the right to counsel on appeal in the face of the discretionary provisions of section 1915(d). 60 Those holdings also ran counter to the terms of section 1915(a) that "an appeal may not be taken in forma pauperis if the trial court certifies in writing that it is not taken in good faith."61 Such certification was entered by the trial courts in Johnson ${ }^{62}$ and Coppedge, 63 but in both cases the Court remanded to the circuit court for further proceedings, with counsel representing the prisoner. Thus, even more specific statutory recognition of trial court discretion than that embodied in section 1915(d) was disregarded by the Court.

In Coppedge, however, the Supreme Court laid down standards for considering in forma pauperis appeals, that appear to take into account the possibility of the poor prisoner abusing his rights. The circuit courts were instructed:

[I] from the face of the papers he has filed, it is apparent that the applicant will present issues for review not clearly frivolous, the Court of Appeals should then grant leave to appeal... appoint counsel to represent the appellant and proceed to consideration of the appeal on its merits.... If, on the other hand, the claims made or the issues sought to be raised by the applicant are such that their substance cannot adequately be ascertained from the face of the defendant's application, the Court of Appeals must provide the would-be appellant both with the assistance of counsel and a record of sufficient completeness to enable him to attempt to make a showing that the District Court's certificate of lack of "good faith" is in error and that leave to proceed with the appeal ... should be allowed. 64

If these rules were carried over to the section 2255 proceedings, they would plainly give the prisoner an opportunity to advance a valid claim for relief. Still the trial court would be justified in refusing to consider appointment of

59 Thomas v. United States, 308 F.2d 369 (7th Cir. 1962). Accord, Way v. United States, 200 F. Supp. 539, 540 (D. Colo. 1961); Hayes v. United States, 194 F. Supp. 807 (D. Colo. 1960); United States v. Owens, 186 F. Supp. 653 (S.D.N.Y. 1960); $c f$. Vinson v. United States, 235 F.2d 120, 122 (6th Cir. 1956).

60 See note 15 supra.

61 See note 14 supra, third paragraph.

62 Johnson v. United States, 352 U.S. 565 (1957).

63 Coppedge v. United States, 369 U.S. 438 (1962).

64 Id. at 446. 
counsel when the prisoner's motion was clearly frivolous. An adequate alternative rule might charge the court with considering the motion, files and records of the case and allow it to refuse counsel only when those records together showed conclusively that the prisoner was entitled to no relief. This rule is already prescribed by section 2255 as the standard by which the trial court must determine whether to grant a hearing on the motion. 65 It differs from the Coppedge rule for appeals only in that it places the burden of searching the records upon the court instead of the court-appointed attorney. Any broader use of the trial court's discretion to disallow counsel, such as basing disallowance on the uncounselled prisoner's motion alone, would seem undesirably to limit the effectiveness of section 2255 for the indigent. 66

A standard such as was set forth in Coppedge to determine whether counsel should be appointed to represent the indigent movant would also seem to provide a satisfactory resolution to the problem of the stage of the proceedings at which counsel should be appointed. The principle of that standard is that assistance of counsel should be forthcoming as soon as it appears that the prisoner's motion is not clearly frivolous. Such a rule would provide the section 2255 movant assistance in the gathering of evidence and testimony to substantiate his motion before the hearing as well as in the presentation of such evidence at the hearing. It would not, however, guarantee assignment of counsel to every prisoner who managed to file a motion.

Strict limitation upon the trial court's discretion in disallowing counsel, should right to counsel be extended to section 2255 proceedings, raises the practical consideration of the additional burden on the bench and bar implicit in the provision of free legal services. Should the right to counsel be applied retroactively, the courts may well be faced with numerous motions from those

65 See note 6 supra, third paragraph.

66 In discussing the extension of right to counsel as a matter of fair criminal procedure, notice should be taken of the argument for equal treatment of prisoners in the courts. The Supreme Court, in the controversial case of Griffin v. Illinois, 351 U.S. 12 (1956), and again in Coppedge, indicated that it was basing the indigent's rights in criminal litigation upon the principle of "equal treatment of all litigants before the bar." 369 U.S. at 447. If the equal treatment doctrine were applied to right to counsel, all circuit court holdings denying counsel to the indigent under $\$ 2255$ would be invalid unless representation for the solvent prisoner by retained counsel were similarly denied or limited.

However, the principle of equal treatment for all litigants, carried to its logicalconclusion, proves too much. It is more reasonable to say that the Court was not advancing a dogmatic pronouncement of equal treatment in either Griffin or Coppedge. Rather, the Court was establishing, in both cases, certain standards of minimally fair criminal procedure. See Allen, Griffin v. Illinois: Antecedents and Aftermath, 25 U. CHI. L. REv. 151 (1957). Subsequent to the Griffin decision, the Court reaffirmed the fundamental fairness test of Betts v. Brady, 316 U.S. 455 (1942), which permitted the criminal trial of indigents, without representation by counsel, in the state courts so long as the fundamental fairness of the trial is demonstrated. This would seem to be sufficient indication that the Court is not enforcing the doctrine of equal treatment "to the greatest possible extent" in the field of right to counsel. See Coppedge, 369 U.S. at 446. 
prisoners who were not granted counsel on previous motions. 67 Commentators disagree, however, as to the substantiality of the burden of free legal aid to indigents. 68 The Supreme Court has not considered the burden a proper counterbalance to the necessity of fairness to indigents in other federal criminal litigation, beyond the provision in Coppedge of minimum safeguards against abusive use of free legal aid. It would not seem justifiable to refuse counsel under section 2255 proceedings solely because of the resulting additional cost.

\section{III}

There remains for consideration the minority rule of the circuit courts, an intermediate position between free allowance of counsel and appointment of counsel according to court discretion: That a prisoner's right to counsel depends upon the type of claim raised in his section 2255 motion. The Massachusetts District Court in Green v. United States, 69 held that when the issues raised by the motion involve questions of fact, the prisoner is entitled to counsel. When they involve only issues of law, appointment of counsel is not necessary. Green has been followed in the Fourth and Fifth Circuits 70 and most recently in the Ninth Circuit case of Dillon $v$. United States. 71 The Second Circuit case of United States $v$. Paglia, 72 the one circuit decision susceptible of a reading that there is a general right to counsel under section 2255 , is, on its narrow holding, also in accord with Green. ${ }^{73}$

The Green holding is patterned after the Supreme Court decision in United States $v$. Hayman, ${ }^{74}$ which held that the prisoner had a right to be present at his section 2255 hearing whenever the issues raised involve the giving of testimony, cross-examination and the like in order to settle factual questions. ${ }^{75}$ The Hayman decision presents strong support for an argument that the pris-

67 It is beyond the scope of this comment to discuss at length the feasibility of retroactive or prospective application of the right to counsel in $\$ 2255$ proceedings. The problem is perhaps a difficult one in view of the fact motions may be filed at any time while the prisoner remains incarcerated. For a discussion of retroactive application of federal rulings in general, see Note, 71 YALE L.J. 907 (1962). Particularly germane to the subject of right to counsel is the note's discussion of Griffin v. Illinois, supra note 66, and of the effect of retroactivity upon court administration. Note, supra, 938-40, 950-51.

68 Compare Williams, The Indigent Defendant: The Problem in the Light of Recent Decisions, 45 A.B.A.J. 174 (1959) (attorneys will be swamped and will balk), with Rann, Appointment of Counsel as a Matter of Right on Criminal Appeals, 23 Albany L. Rev. 114, 121-22 (1959) (attorneys respond "willingly and cheerfully" to assist indigents).

69158 F. Supp. 804 (D. Mass.), aff'd, 256 F.2d 483 (1st Cir. 1958).

70 United States v. Neims, 190 F. Supp. 677 (W.D. Va. 1960), aff'd on other grounds, 291 F.2d 390 (4th Cir. 1961); United States v. Pruitt, 121 F. Supp. 15 (S.D. Tex.), aff'd, 217 F.2d 648 (5th Cir. 1954), cert. denied, 349 U.S. 907 (1955).

71307 F.2d 445 (9th Cir. 1962). 72190 F.2d 445 (2d Cir. 1951).

73 The case was remanded for hearing with counsel representing the prisoner, but the issues remanded for hearing were questions of fact.

74342 U.S. 205 (1952).

75 Id. at $222-23$. 
oner should also have legal representation in the technical process of questioning witnesses and presenting testimony to establish facts that would support his claim for relief. The fact that the legally untrained prisoner is present will hardly insure a fair hearing if he is then left to his own devices in the calling and questioning of witnesses.

It is, however, not so obvious that the prisoner should not also be represented by counsel when his motion involves only issues of law. It will likely be of no benefit to the fair disposition of the motion, based on claims of law alone, that an indigent and legally untrained prisoner is present to guide the court's deliberations at the hearing. On the other hand, it is difficult to support a contention that the arguments of counsel will not promote such a fair disposition, just as will the briefs and arguments of counsel on an appeal.

Even if the seemingly arbitrary distinction of fact and law issues under the Green doctrine are ignored, it should be noted that Green again places the indigent prisoner in the position of having to pass a preliminary test before he is entitled to the aid of counsel. ${ }^{76} \mathrm{He}$ must, by his own efforts, raise particular issues-that is, issues of fact-before he may have help. This preliminary test will often be more difficult to meet than one patterned after the Coppedge rule, which would require only the raising of any non-frivolous issue in the motion before counsel was granted.77

\section{CONCLUSION}

Circuit court decisions that deny or limit right to counsel under section 2255 proceedings leave an unwarranted inconsistency in the fabric of protection for the accused in federal criminal litigation. The holdings do not demonstrate that the prisoner is in less need of legal assistance in order fairly and effectively to employ the statutory machinery to regain his freedom, than if he were appealing his conviction directly. Nor do they advance significant reasons for applying different standards to such proceedings than to direct appeals when deciding what constitutes fair criminal procedure in the federal courts.

Prior holdings of the Supreme Court in other contexts, and particularly in Hayman, ${ }^{78}$ may indicate that as a minimum measure the federal courts ought to adopt the Green 79 holding that there is a right to counsel when the motion raises issues of fact. However, even Green places an artificial limitation on the extension of right to counsel in the federal courts, a limitation that can only be justified by arbitrary distinction-drawing. It is not necessarily correct that the courts are never justified in making arbitrary distinctions for the purpose

76 See text accompanying note 59 supra.

77 The Green test is also more difficult to meet than the test a prisoner must pass under $\$ 2255$ before he is granted a hearing on his motion. See note 6 supra, third paragraph.

78 United States v. Hayman, 342 U.S. 205 (1952).

79 Green v. United States, 158 F. Supp. 804 (D. Mass.), aff'd, 256 F.2d 483 (1st Cir. 1958). 
of confining a principle of law, but it is difficult to make such a justification where human life or liberty is involved. In any case, such a device ought to be employed only when the principle sought to be confined is capable of extension ad absurdum throughout a particular field of law. No such principle seems to be involved here. To extend a general right to counsel to section 2255 proceedings would complete the process of recognizing that representation by counsel is a necessary part of all fair criminal procedure in the federal courts. As the logical completion of this process, the extension would open no floodgates of further extension in federal criminal litigation.

This is not to say that right to counsel under section 2255 ought to guarantee judicial sanction and succor to the obviously frivolous motion of the indigent prisoner who will try anything in order to get out of jail. The Supreme Court has met the problem of abuse of the right to counsel in prisoner-initiated appeals. In Coppedge, 80 the Court prescribed a rule that at once guarantees maximum protection, including aid of counsel, to the poor prisoner who advances a colorably valid claim in his petition for appeal, while empowering the courts to refuse counsel and summarily deny the petition containing conclusively invalid claims. It is submitted that the extension of the right to counsel, along with a minimum limitation like the Coppedge rule, to section 2255 proceedings would elevate these proceedings to a level of fairness consonant with other federal criminal litigation.

80 Coppedge v. United States, 369 U.S. 438 (1962). 